\title{
SENSE OF MULTIKULTURALISME: POTENSI INTEGRASI DALAM KELOMPOK TEATER PELAJAR SMA DI KOTA SOLO
}

\author{
Isa Ansari' ${ }^{1}$, Achmad Dipoyono ${ }^{2}$ \\ Jurusan Pedalangan, Fakultas Seni Pertunjukan \\ Institut Seni Indonesia (ISI) Surakarta \\ 1Email : ansori@isi-ska.ac.id \\ ${ }^{2}$ Email : dipoyono@isi-ska.ac.id
}

\begin{abstract}
In general, this study departs from a large scheme of research on Sense of Multiculturalism initiated by the Center for Theater Studies and Social Integration. This is a basic research to explore the potencies that exists among adolescents, both related to the conflict as well as efforts to integrate in high school theater groups. Problems of this research include; first, what potencies that can lead them into conflict areas? What potencies that develops in youth theater groups that can anticipate and strengthen the social integration? Data collection is done by interview, observation, and documentation. The results of this study indicate that the potencies that directs group members into conflict is due to the impartiality experienced by students participating in theater extracurricular activities, both from the school as well as from their family. But their potencies in integration is stronger than the potencies in conflict, namely independence, maturity, togetherness, cooperation, and kinship among members of the student theater group.
\end{abstract}

Keywords: integration, conflict, students theater

\section{Pendahuluan}

Di Kota Solo setidaknya terdapat sekitar 15 sekolah menengah atas yang menyelenggarakan teater sebagai kegiatan ekstrakurikuler (ekskul). Ke 15 sekolah ini adalah SMAN 1, SMAN 2, SMAN 3, SMAN 4, SMAN 5, SMAN 6, SMAN 7, SMAN 8, SMAN 9, SMA Batik 1, SMA Muhammadiyah 2, SMA Muhammadiyah 4, SMA Santo Yosef, SMK 4, dan SMA Kristen Kalam Kudus, Siswa-siswa yang aktif di teater sekolah tersebut kemudian membentuk kelompok-kelompok teater dengan nama yang berbeda-beda, seperti Teater Biroe (SMA Santo Yoesef), Citra Mandiri (SMAN 2), Teater Prada (SMA Batik 1), Teater Lintang (SMA N 8), dan Teater Timboel (SMA N 5), Teater Tulang (SMA N 6).

Dua pertanyaan yang akan dijawab dari penelitian ini, yakni bagaimana potensi konflik yang muncul dikalangan kelompok teater? dan hal-hal apa yang dapat memunculkan potensi integrasi dari proses beteater yang mereka jalankan?

Untuk melihat kedua potensi tersebut, penelitian ini difokuskan pada enam kelompok teater sekolah tingkat SLTA yang ada di Kota Solo, yakni Teater Citra Mandiri (Ciman) yang berada di SMA Negeri 2 Surakarta, Teater Lintang dari SMA Negeri 8 Surakarta, Teater Prada yang berada di SMA Batik 1 Surkarta, Teater Timboel dari SMA Negeri 5 Surakarta, dan Teater Biroe yang berasal dari SMA Pangudi Luhur Santo Yosef Surakarta. Keenam sekolah ini dipilih berdasarkan beberapa pertimbangan. Pertama karena kalompok-kelompok teater di sekolah sekolah tersebut masih aktif dan cukup eksis untuk wilayah Surakarta, walaupun ada dari kelompok tersebut yang sudah cukup lama tidak melakukan pertunjukan secara mandiri seperti SMA Batik 1 Surakarta. Namun rutinitas 
latihan tetap mereka lakukan, dan beberapa kali mereka ikut dalam festival sandiwara pelajar. Kedua, kenam kelompok teater tersebut dapat dikelompokan menjadi tiga berdasarkan pada perbedaan keyakinan yakni, Teater Prada SMA Batik 1 berbasis Islam, Teater Biroe Santo Yosef berbasis non Muslim, dan beberapa sekolah negeri yang tidak merujuk pada salah satu keyakinan keagamaan.

Layaknya organisasi sekolah, kelompok-kelompok teater ini juga mempunyai struktur organisasi dengan pembagian tugas dan wewenang yang jelas. Walaupun dalam kenyataanya struktur tersebut tidak berjalan efektif, karena kegiatan yang mereka lakukan pada dasarnya adalah rutinitas yang selalu berulang.

Kelompok-kelompok teater ini beranggotakan siswa di sekolah tersebut, mulai dari siswa kelas I hingga kelas III. Jumlah anggota dalam satu kelompok rata-rata sebanyak 20-30 orang pelajar. Anggota kelompok yang bersifat eksklusif dalam artian hanya siswa dari sekolah tersebut, bukan berarti kelompok tersebut juga bersifat eksklusif terhadap kelompok teater dari sekolah yang lain. Karena pada dasarnya anggota kelompok teater sekolah tersebut juga merupakan anggota dari kelompok teater lain yang berada di luar institusi sekolah. Selain itu pada tahun 2011 di Solo dibentuk Jaringan Teater Pelajar (JTP) yang bertujuan untuk mengkoordinir kelompok teater pelajar. JTP berperan penting dalam mengembangkan kelompok-kelompok teater pelajar yang stagnan, terutama yang disebabkan oleh tidak adanya pelatih. Melalui JTP inilah anggota-anggota senior dan berpengalaman dapat membantu sekolah-sekolah yang belum mempunyai pelatih teater.

Bertemunya anggota-anggota kelompok teater sekolah dalam satu keanggotaan kelompok teater di luar sekolah membuka sekat-sekat eksklusifitas kelompok teater sekolah, sehingga dalam suatu pertunjukan teater yang diproduksi oleh kelompok suatu sekolah tak jarang kita menemukan pemain yang berasal dari sekolah lain. Bahkan hampir dalam setiap pementasan ketika saat melakukan setting panggung temanteman mereka yang berasal dari sekolah lain juga turut membantu.

Karakteristik lainnya dari teater pelajar tersebut adalah "suporter" pertunjukan. Setiap sekolah mempunyai "suporter" pada saat kelompok teater dari sekolah tersebut tampil. Dua realitas yang sama peneliti jumpai terkait dengan suporter pertunjukan ini. Pertama, pada saat festival sandiwara realis pelajar yang diselenggarakan oleh HIMATIS (Himpunan Mahasiswa Teater ISI Surakarta) yang diikuti oleh 8 sekolah menengah atas yang terdiri dari 4 SMA yang berasal dari Solo dan 4 sekolah lainnya berasal dari luar Solo. Pementasan yang menampilkan peserta dari Solo selalu ditonton oleh banyak orang, bahkan gedung Teater Kecil yang berkapasitas 300 kursi tidak cukup untuk menampung merupakan siswa dari sekolah yang tampil. Seperti pada saat penampilan kelompok teater Citra Mandiri dari SMAN 2 surakarta yang dipadati oleh penonton yang sebagian besar adalah siswa sekolah tersebut. Layaknya suporter pertandingan sepak bola mereka memberikan dukungan dengan cara bertepuk tangan pada saat akan dimulainya pertunjukan dan akhir pertunjukan. Ketika ada adegan yang lucu, seperti di komando serentak mereka tertawa bersama. Hal tersebut juga dilakukan oleh kelompok teater yang lain. Hadirnya suporter ini tidak hanya pada saat kelompok teater dari sekolah tersebut tampil, tetapi mereka juga terlibat aktif pada saat anggota dari kelompok tersebut ikut terlibat dalam suatu pertunjukan yang diproduksi oleh kelompok teater yang lain. Bahkan dukungan ini juga mereka berikan terhadap alumni dari SMA kelompok teater tersebut.

Karakterisktik lainnya yang merupakan kekuatan dari teater pelajar di Kota Solo adalah kemampuan mereka untuk mementaskan dengan mengunakan bahasa Jawa. Tidak banyak kelompok-kelompok teater remaja di Indonesia yang mampu mementasakan pertunjukan dengan 
menggunakan bahasa daerah, terutama pada pertunjukan yang menggunakan naskah-naskah terjemahan. Tidak hanya pada saat festival teater berbahasa Jawa saja kemampuan mereka ditunjukan, namun dalam pementasan-pementasan rutin tak jarang mereka mementaskan dengan menggunakan bahasa Jawa. Seorang teman yang merupakan dosen teater di ISI Padang Panjang kagum dengan kemampuan para pelajar yang dapat mengalihbahasakan dan mewujudkannya dalam pertunjukan dari naskah yang berbahasa Indonesia ke bahasa Jawa. Pernyataan senada juga dilontarkan seorang dosen teater ISI Yogyakarta, bahwa tidak banyak kelompok-kelompok teater remaja di Yogyakarta yang mau dan mampu mementaskan pertunjukan dengan menggunakan bahasa Jawa.

Kemandirian, adalah karakteristik lain dari kelompok teater pelajar yang ada di Kota Solo. Kemandirian ini dapat dilihat dari pengakuan sekolah terhadap kelompok teater tersebut. Dari data yang didapatkan, sebagian besar kelompok teater tersebut pada awal berdirinya tidak mendapatkan pengakuan resmi dari sekolah. Hal ini berimplikasi terhadap dana operasional yang tidak masuk dalam penganggaran kegiatan rutin di sekolah baik untuk aktifitas rutin yang mereka selenggarakan, seperti latihan ataupun kegiatan-kegiatan luar yang harus mereka ikuti.

\section{Pembahasan}

Berteater bagi sebagian orang memunculkan stereotype sebagai kegiatan yang sia-sia, bebas, urak-urakan dan mengumbar imaginasi, sehingga stereotype ini tidak hanya dilekatkan pada aktifitas berteater, bahkan juga terhadap mereka yang terlibat pada kegiatan tersebut. Gayung bersambut, stereotype ini seolah-olah mendapatkan pembenaran dari realitas yang dihadirkan oleh sebagian pelakupelaku teater. Oleh karenanya banyak dari orang tua yang tidak mengijinkan anak-anaknya untuk terlibat dalam kelompok teater, karena ketakutan mereka terhadap stereotype tersebut. Pandangan ini juga muncul dari kalangan pendidik di sekolah-sekolah menengah atas (SLTA).

Bagi sebagian yang lain (siswa) tidak terganggu dengan stereotype di atas karena bagi mereka teater menghadirkan sesuatu yang berbeda secara psikososial. Penampilan fisik yang sering diwujdukan oleh pelaku teater, pada dasarnya adalah sebagai pencarian pengakuan terhadap aktifitas teater yang dilakukan. Mereka yang aktif berteater di sekolah-sekolah tersebut mempunyai argument-argumen yang berbeda terkait dengan keikutsertaan mereka di teater sekolah. Berikut ini disampaikan beberapa alasan yang melatarbelakangi mereka untuk ikut dalam ekgiatan ekskul teater.

Pertama adalah karena disposisi estetis yang pernah mereka alami, karena sebelumnya mereka pernah terlibat langsung dalam teater baik pada saat sekolah dasar, saat sekolah menengah pertama, atau kelompok-kelompok teater yang berada di luar sekolah. Seperti Devina dan Pitaloka yang merupakan anggota Teater Lintang, sudah mengenal teater sejak SMP. Bahkan Olivia Firdaus, anggota Teater Timboel, Lenta Maria dari Teater Biroe, dan Masyithoh Aulia dari Teater Prada, ketiganya sudah aktif berteater sejak SD. Berbeda dengan Olivia dan Lenta, perkenalan Masyithoh sejak dini dengan teater karena ayahnya adalah seorang pemain teater dan sejak SD ayahnya sering mengajaknya untuk menonton teater.

Kedua, adalah karena imaji estetis, yakni karena mereka mendapatkan pengalamanpengalaman visual dari pertunjukan atau aktifitas-aktifitas berteater yang pernah mereka lihat. Dari sini kemudian mereka membangun imaji-imaji estetis yang suatu saat akan mereka wujudkan. Seperti yang dilakukan oleh Rara dan Kresen keduanya adalah anggota Teater Biroe. Mereka mempunyai kakak perempuan yang juga aktif di teater, mereka berdua akhirnya 
tertarik ikut ekskul teatear, karena sering melihat kakak-kakak mereka berlatih teater di sekolah cerita-cerita yang disampaikan oleh kakakkakak mereka yang pada dasarnya terkait dengan hal-halm positif dan yang menggembirakan selama ikut dalam kelompok teater. Kakak perempuan dari Rara adalah mantan anggota Teater Biroe dan saat ini telah lulus dari SMA Yosef, sedangkan kakak perempuan dari Kresen merupakan anggota Teater Tulang yang telah lulus dari SMA N 6. Seringnya melihat kakak mereka bersenang-senang dengan teater, menimbulkan rasa penasaran bagi Kresen dan Rara. Hal ini yang mendasari mereka ikut dalam kelompok teater tersebut dan hingga saat ini mereka menikmati proses berteater yang mereka ikuti.

Ketiga, adalah karena keingintahuan mereka terhadap teater, kelompok yang ketiga ini belum pernah mendapatkan pengalaman secara visual ataupun disposisional. Mereka hanya sering mendengar kata teater namun belum pernah melihat pertunjukan teater. Keingintahuan ini menguat pada saat display kegiatan ekstra kulikuler (ekskul) saat masa orientasi siswa (MOS). Seperti Lenta dan Wina dari Teater Biroe yang tidak memiliki latar belakang keluarga yang berkecimpung di dunia seni. Mereka juga belum pernah melihat pertunjukan teater, naman rasa penasaran menarik mereka untuk ikut kegiatan ekskul teater ketika display ekskul pada masa orientasi sekolah(MOS). Setidaknya 70 persen siswa yang diwawancarai, mengatakan bahwa keterlibatan mereka di teater awalnya karena keingintahuan mereka terhadap teater. Hanya 1 orang dari 23 siswa yang mengatakan bahwa keikutsertaannya di teater karena diajak oleh teman dan selebihnya sebagaimana alasan yang pertama dan kedua.

Ketiga alasan di atas tidaklah membedakan militansi mereka dalam berteater. Baik karena alasan keingintahuan ataupun karena memang sudah mengenal teater keduanya sama-sama merasa enak dan dapat menikmati aktifitas mereka berteater. Mereka aktif berproses baik karena untuk kebutuhan pertunjukan, ataupun hanya sekedar rutinitas latihan. Karena tidak semua dari anggota kelompok tersebut berkesempatan untuk main dalam satu pertunjukan teater. Bahkan ada dari kelompok teater yang belum pernah memproduksi suatu pertunjukan yakni Teater Prada dari SMA Batik 1. Namun hal ini tidak menurunkan semangat mereka untuk selalu berproses.

Jika dilihat secara keseluruhan alasan keterlibatan mereka di teater pada dasarnya hal tersebut dilandasi oleh kemauan individuindividu. Bahkan ada dari beberapa sisiwa yang mendapat pertentangan dari orang tua mereka, namun hal tersebut tidak menyurutkan semangat mereka untuk terus beraktifitas di teater. Hal ini menunjukkan tingkat militansi mereka yang cukup tinggi baik terhadap sanggar yang menjadi tempat mereka berlatih. Hal tersebut juga berimplikasi terhadap tingginya solidaritass antar mereka, tidak hanya terhadap siswa-siswa yang masih aktif, namun juga terhadap alumnialumni dari sekolah tersebut. Karena teater mengikat mereka secara emosional.

\section{Persoalan yang muncul}

Keenam kelompok teater di Solo tersebut mempunyai persoalan yang berbeda-beda, sehingga cara penyelesaian yang mereka tawarkan juga berbeda-beda. Namun secara keseluruhan ada beberapa persoalan yang muncul baik dalam hubungannya dengan sesama teman di dalam kelompok tersebut, ataupun konflik yang muncul antara mereka dengan orang diluar kelompok tersebut.

\section{Persoalan antar anggota}

Pertama adalah persoalan dengan sesama teman di dalam kelompok teater. Konflik ini muncul pertama terkait dengan pembagian peran untuk suatu proses pertunjukan. Penentuan untuk memerankan tokoh tertentu dilakukan dengan cara penunjukan langsung atau dengan 
dilakukannya casting. Terkadang actoraktor yang mendapatkan peran tidak sesuai dengan yang diharapkan. Hal ini terkadang menimbulkan perselisihan antar actor seperti yang diceritakan oleh Frisca Fricilia dari Teater Ciman. Seperti yang dilakukan oleh salah satu anggota Teater Citra Mandiri (Ciman). Produksi terbaru mereka tahun 2018 ini berjudul Nyai Ontosoroh dengan para pemain dari anggota baru. Casting telah ditentukan, latihan pun telah berjalan hingga $\mathrm{H}-7$, ada permasalahan pada aktor yang memerankan tokoh Anelis. Selama latihan, Dia (nama samaran) dinilai kurang serius dan kurang fokus. Beberapa anggota lain seperti Gladys, Cila (Fricilia), dan Nabila telah berusaha mengajak Dia bicara soal masalah keaktorannya. Usaha itupun tidak membuahkan hasil, sehingga Yogi (sebagai pelatihnya) merasa aktor ini perlu diganti, karena tokoh Anelis membutuhkan keseriusan. Akhirnya, tokoh Anelis diperankan oleh Anggita.

Pergantian peran ini menimbulkan sedikit masalah, tetapi cukup mengganggu. Setelah selesai euforia pementasan, Dia tidak lagi muncul dan hadir dalam acara maupun latihan rutin Teater Ciman, Cila berusaha menghubungi dan mengajaknya kembali mengikuti ekskul teater. Permintaan itu ditolak Dia, dengan alasan sudah tidak diperbolehkan ikut teater oleh kedua orang tuanya, karena sering pulang malam.

Persoalan yang muncul dengan sesama anggota teater ini juga pernah dialami oleh Masyithoh anggota dari Teater Prada yang disebabkan oleh persaingan antar anggota. Persoalan muncul pada saat mereka mengikuti seleksi perlombaan baca puisi. Teman Masyitoh, sebut saja XX mengikuti seleksi tersebut, namun dia tidak lolos, yang lolos hanya Masyithoh degan seorang temannya, yang juga merupakan teman dari XX. Hal ini memicu perselisihan keduanya. Masyitoh berusaha untuk tetap membangun hubungan baik dengan XX, dengan tetap mengajak berbicara, bercanda dan hal-hal lain yang tidak terkait dengan masalah yang mereka hadapi.

Kedua, Selain disebabkan oleh pergantian peran, persoalan internal juga dapat muncul karena adanya perbedaan pendapat dalam memahami naskah ataupun dalam menjalankan organisasi. Perbedaan pendapat ini sering menyebabkan perdebatan antar anggota. Terkait dengan perbedaan dalam memahami naskah, hal ini lumrah terjadi dalam proses berteater, pada konteks ini biasanya para anggota berusaha untuk mempertemukan pandangan mereka yang berbeda dengan terus melakukan diskusi, hingga menghasilkan persamaan pandangan. Hal ini diperlukan karena dalam suatu pertunjukan tidak mungkin ada perbedaan pemahaman. Efek yang sering muncul dari perbedaan pendapat ini adalah pergunjingan dan pembentukan kubukubu antar orang yang berselisih pendapat. Hal ini menunjukkan bahwa perbedaan dalam memahami naskah, dapat meningakt eskalasinya jika tidak dikelola dengan baik

Ketiga, persoalan lain yang sering dihadapi oleh sebagai besar kelompok teater pelajar adala ketidakdisiplinan anggota, terutama saat latihan. Di teater Biroe misalnya, dalam setiap latihan selalu ada anggota yang datang terlambat, atau bahkan tidak hadir pada saat latihan. Persoalan ini dianggap biasa atau wajar dalam kegiatan ekstrakulikuler, karena hal yang sama juga dihadapi oleh kegiatan ekskul yang lain. Namun, untuk mendisiplinkan keanggotaan, para pengurus atau anggota-anggota yang aktif dan pelatih selalu mengingatkan hal tersebut kepada semua anggota pada setiap latihan. Ketidakdisiplinan anggota ini terkadang juga menyebabkan mereka keluar dari keanggotaan. Seperti yang diceritakan oleh Anggita terhadap empat orang temannya dekatnya yang saat ini sudah keluar dari keanggotaan teater Cimen, SMA N 2. Mereka berlima adalah teman dekat yang selalu bersama, begitu juga saat masuk menjadi anggota teater Cimen. Selama proses latihan empat orang temannya sering dating terlambat, dan terkang tidak hadir dan pada 
akhirnya mereka keluar sebagai anggota teater tersebut. Menurut penuturan Angita, mereka keluar dari keanggotaan tersebut karena merasa tidak nyaman dengan sering dating terlambat dan terkadang tidak hadir pada saat latihan. Namun hal ini tidak merubah pertemanan mereka, karena hingga saat ini di luar kegiatan berteater mereka sering bersama.

Keempat adalah konflik structural. Konflik ini terdiri dari konflik antara anggota dengan sekolah. Seperti yang dialami oleh Teater Lintang dari SMA Negeri 8 Surakarta, konflik terjadi karena pihak sekolah tidak mau memberikan dana pada saat akan pentas yang memaksa mereka untuk iuran. Begitu juga yang dialami oleh Teater Timboel dengan wakil kepala sekaloh bidang Kesiswaan yang seharusnya mengetahui jerih payah siswa yang berproses, justru tidak menanggapi dengan baik saat siswa memberikan laporan terhadap pembina yang kurang kooperatif dengan siswa. Selain itu pada saat Teater Timboel di undang untuk pentas mengisi acara di luar sekolah, diperingatkan oleh Waka Kesiswaan dan pembina untuk tidak membawa nama sekolah. Sementara itu, Teater Timboel adalah salah satu ekskul resmi di SMA N 5 Surakarta. Hal ini menimbulkan kekecewaan mendalam bagi siswa yang mengikuti ekskul teater. Para anggota teater sangat kecewa dengan sikap dari Waka Kesiswaan tersebut dan menyebabkan timbulnya ketidakpercayaan terhadap wakasek tersebut, dan sering menjadi pergunjingan antar anggota.

Konflik structural yang dihadapi Teater Timboel jauh lebih kompleks dibandingkan dengan kelompok teater lainnya. Karena selain perselisihan dengan wakil kepala sekolah bidang kesiswaan, selisih faham juga muncul antara siswa dengan pembina. Hal ini disebabkan peran-peran pembinaan yang seharusnya dilakukan oleh guru tersebut tidak dilakukan, bahkan menurut siswa guru tersebut cenderung mempersulit kegiatan teater yang mereka lakukan. Persoalan yang serupa juga terjadi pada teater Biroe. Guru yang menjadi pembina mereka justru membuat kelompok drama sendiri dengan anggotanya beberapa siswa yang diajar oleh beliau. Hal ini memicu masalah dengan pelatih Teater Biroe, juga mempengaruhi hubungan siswa dengan pembina. Tetapi persoalan tersebut dapat teratasi setelah mereka menyampaikan persoalan tersebut kepada Kepala Sekolah . Tahun ajaran baru ini mereka memiliki pembina baru, harapan mereka semoga pembina baru juga mampu mengayomi Teater Biroe.

Kelima, adalah konflik antara anggota teater dengan pelatih seperti yang pernah dialami oleh Teater Timboel. Siswa menganggap bahwa pelatih memberikan materi yang membosankan, tidak variatif dan terlalu banyak teori yang disampaikan. Selain itu, pelatih menyetir penuh terhadap keputusan yang akan diambil oleh siswa. Siswa merasa seperti boneka, karena tidak diberi kepercayaan dan kebebasan dalam berpendapat dan bertindak. Olivia dan Fadila khawatir apabila persoalan ini terus terjadi, Teater Timboel justru akan mengalami penurunan kualitas dan kuantitas. Untuk menyelesaikan hal tersebut mereka

Keenam konflik antara anggota dengan pengurus kelompok teater pelajar, seperti yang diceritakan oleh Sae (nama samaran) terkait dengan tim produksi. Saat membuat suatu pertunjukan, urusan administrasi terutama terkait dengan surat menyurat harus cepat dilakukan. Namun Sae dinilai kurang cepat dalam menyelesaikan tugasnya, padahal waktu pertunjukan tinggal 1 minggu. Anggota lain yang memerlukan surat harus menunggu, terkait dengan undangan, peminjaman peralatan, peminjaman tempat secara resmi, walaupun secara lisan sudah disampaikan kepada Kepala Taman Budaya Jawa Tengah, dan surat-menyurat lainnya. Sae pun sudah mendapat teguran dari teman-temannya, tetapi tidak merubah kinerjanya. Ketua teater Ciman kemudian meminta anggota lain untuk membantu tugas- 
tugas Sae. Hal ini menimbulkan kekecewaan pada diri Sae, karena merasa kerjanya tidak dihargai. Kemudian Sae mengundurkan diri, karena alasan tidak mendapat izin dari orang tua, sehingga kerja-kerja sekretaris diambil alih oleh anggota yang lain.

Sebagaimana diketahui bersama bahwa dalam suatu pementasan, peran tim produksi sangat vital, setara dengan sutradara dan aktor, karena segala kebutuhan teknis, administrative, finansial menjadi tanggung jawab tim produksi.

\section{Persoalan eksternal}

Persoalan eksternal yang mereka hadapi pada dasarnya terkait dengan orang tua mereka. Fadila juga mendapat kendala dari orang tua yang agamis dan memandang seni sebelah mata. Terkadang orang tuanya sangat melarang kegiatan teater yang menurut Fadila menyenangkan. Fadila merasa teater memberikan ruang dan kesempatan untuk lebih dekat satu anggota dengan anggota yang lain, seperti mendapat keluarga baru. Bahkan Fadila lebih percaya diri untuk ikut serta dalam drama di kampunya, dan mendapat kesempatan untuk menjadi aktor yang penggagas ide cerita. Tetapi hal ini tidak sebanding dengan sikap orang tuanya yang justru membatasi kegiatan Fadila di kampung. Fadila juga tidak nyaman, saat Fadila absen acara pertemuan keluarga. Sementara itu, Fadila yang harus harus les atau harus mengikuti kelas tambahan, justru orang tuanya menjadikan teater sebagai alasan ketidakikutan Fadila dalam acara keluarga, dan seperti telah menjadi kebiasan orang tuanya.

Hal yang sama dialami oleh Olivia. Dia terkadang cek-cok dengan orang tuanya yang mengangap teater tidak penting, tidak memberikan pengaruh yang besar terhadap masa depan. Stereotype negative yang disematkan terhadap orang yang aktif dalam dunia teater menjadi alasan kedua orang tuanya untuk melarang keterlibatan Olivia di dunia teater. Namun dia meyakini bahwa teater tidak hanya proses dan bersenang-senang namun lebih dari itu dapat membangun kemandiriannya.

\section{Cara menyelesaikan masalah}

Keterlibatan mereka di teater yang dihadapkan dengan berbagai masalah mendewasakan mereka dalam mengambil keputusan untuk menyelesaikan atau kalau tidak inisiatif-inisiatif solusi yang mereka tawarkan. Secara umum cara penyelesaian konflik yang mereka alami adalah dengan tidak melibatkan pihak ketiga.

\section{Secara internal}

1. Dengan melakukan kompromi Yaitu suatu upaya saling mengurangi tuntutan agar tercapai penyelesaian. Kompromi ini termasuk hal yang sering dilakukan oleh anggota kelompok teater pelajar. Karena pada dasarnya mereka berada pada kedudukan yang sama antara satu kelomok dengan kelompok yang lain.

Melalui kompromi mereka mencoba menyelesaikan konflik dengan menemukan dasar yang mempertemukan dua pihak yang berkonflik. Cara ini lebih memperkecil kemungkinan untuk munculnya permusuhan yang terpendam dari dua belah pihak yang berkonflik, karena tidak ada yang merasa menang maupun kalah. Meskipun demikian, dipandang dari pertimbangan organisasi pemecahan ini bukanlah cara yang terbaik, karena tidak membuat penyelesaian yang terbaik pula bagi organisasi, hanya untuk menyenangkan kedua belah pihak yang saling bertentangan atau berkonflik. Seperti pada penyelesaian konflik yang ketiga. Karena karena pada konflik yang ketiga ini kedua belah pihak yakni antara Anggita dan temannya yang berkonflik yakni dengan menjunjung tinggi hak untuk mengikuti ekskul teater atau tidak. Mereka lebih mementingkan tujuan pertemanan dibandingkan dengan kebersamaan sebagai anggota teater. Penyelesaian dengan cara kompromi juga dilakukan ketika mereka berselisih dengan pihak sekolah, terutama terkait dengan perselihan 
mereka dengan pembina teater.

2. Avoiding - Satu pihak menolak bahwa konflik itu ada, mengubah topik, dan menghindari diskusi-diskusi, seraya tidak memperlihatkan komitmen penyelesaian. Gaya ini efektif dalam situasi dimana terdapat bahaya penyerangan fisik, tanggapan atas isu remeh, tidak berpengaruh terhadap kesempatan untuk mencapai tujuan, atau rumitnya situasi yang membutuhkan solusi (Warren and Spangle, 2000: 26-27).

Dari beberapa cara yang dilakukan siswa dalam menyelesaikan masalah cara avoiding ini lebih banyak dilakukan. Alasan yang mereka kemukakan sangat sederhana yakni tidak ingin persoalan tersebut menjadi berkepanjangan. Di sisi lain cara penyelesaian dengan menghindar ini mempunyai basis kultural dengan masayrakat Jawa yang cenderung tidak ingin masuk dalam ruang konflik. Tujuan-tujuan harmoni lebih mereka kedepankan agar dapat hidup bersama tanpa adanya gangguan. Disadari atau tidak cara ini dilakukan oleh para pelajar dalam menyelesaikan konflik yang terjadi antar mereka.

Avoiding (penghindaran) konflik punya keuntungan dalam hal pemeliharaan hubungan, dalam mana hubungan diyakini akan terus langgeng tanpa harusmengungkin persoalan yang pernah terjadi walaupun dengan tujuan untuk menyelesaikan konflik, mereka mengaggap hubungan akan terluka akibat proses penyelesaian konflik.Kerugiannya gaya ini adalah konflik tidak akan selesai. Berlebihannya penggunaan gaya ini justru mendorong munculnya konflik internal dalam diri individu yang melakukannya. Orang lainpun cenderung meremehkan si penghindar. Penghindaran masalah biasanya bukan malah menyelesaikan masalah melainkan justru menambahnya. Semakin lama kita menunggu konfrontasi dengan orang lain, semakin sulit konfrontasi yang terjadi nantinya (Lussier and Christopher, 2010:212).
3. Dengan cara toleransi, cara ini memberikan peluang pada kedua belah pihak untuk saling memahami dan mengerti, sehingga muncul keberterimaan bersama terhadap persoalan yang muncul. Hal ini dilakukan agar adanya keberterimaan terhadap perbedaan yang muncul dari kedua belah pihak dan tidak menggangu pihak lain yang sedang berkonflik. Hal inilah yang dilakukan oleh Masyitoh ketika berkonflik dengan temannya. Dia menghargai teman akrabnya untuk keluar dari kelompok teater, begitu juga dengan temannya yang menghargai aktifitas Masyitoh di kelompok teater tersebut.

\section{Potensi integrasi}

Kelompok teater pelajar yang ada di kota Solo atau bahkan juga kelompok-kelompok teater pelajar secara umum mempunyai potensi melakukan integrasi karena mereka pada dasarnya mempunyai rasa keberterimaan yang cukup tinggi terhadap perbedaan. Hal ini dapat dilihat dari keanggotaan mereka yang cukup beragam baik dari segi keyakinan keagamaan, jenis kelamin, umur, dan kebudayaan. Berangkat dari wawancara dan questioner yang kami sampaikan kepada mereka, terdapat beberapa hal dari tingkah laku dan polafikir mereka yang berpotensi untuk menciptakan toleransi Proses integrasi dapat dipahami sebuah proses penyesuaian antarunsur dalam masyarakat yang majemuk hingga terbentuk keserasian dalam kehidupan sosial bermasyarakat.

Pertama, bahwa keberagamaan yang menjadi keniscayaan bagi mereka dan makhluk di alam semesta ini tidak harus dipersoalkan. Bahkan mereka mengatakan bahwa "bagi kami perbedaan itu tidak ada, saling menghormati saja kalau ada teman yang beribadah di tengahtengah waktu latihan, atau ijin tidak ikut latihan karena ibadah dulu". Karena bagi mereka perbedaan itu tidak harus dipertentangkan. Perbedaan keyakinan ataupun sukubangsa lebur 
di dalam kebersamaan yang mereka bangun. Hal ini mewujud dalam aktifitas keseharian mereka, disekolah-sekolah negeri (umum) mereka tidak memilih orang-orang yang harus menjadi teman mereka. Di sekolah-sekolah swasta St Yosep yang non muslim dan SMA Batik yang muslim, mereka dibiasakan untuk selalu berinteraksi dengan siapapun, seperti melalui JTP (Jaringan Teater Pelajar) yang menjadi tempat berkumpulnya anggota-anggota teater pelajar di Solo.

Kedua adalah kemudahan mereka dalam memahami pelajaran yang disampaikan oleh guru, walaupun hal ini perlu dilakukan penelitian lebih lanjut terkait dengan korelasi antara aktifitas berteater dengan kemudahan dalam proses pemahaman materi pelajaran. Namun hal ini tidak terkait dengan prestasi kelas, karena untuk menghitung prestasi kelas banyak indicator yang manjadi pengukurnya. Mereka beralasan bahwa dalam proses berteater, kamu selalu dihadapkan pada bacaan dalam bentuk dialog, dan dialog tersebut harus kami tangkap makna atau maksudnya baik secara mikro (dalam konteks dialog tersebut), ataupun secara makro (keseluruhan isi naskah).

Hal ini menunjukkan kemampuan mereka dalam melakukan identifikasi karakter seseorang. Dalam konteks naskah mereka diarah untuk mampu mengidentifikasi struktur dalam naskah. Pembiasaan-pembiasaan tersebut, tentunya akan berimplikasi dalam proses social yang mereka lakukan.

Ketiga, menguatnya kerjasama antar anggota, mereka menjadi lebih solid. Dari ceritacerita yang mereka sampaikan ke peneliti, para pemain teater mengutamakan kerjasama dalam kegiatan yang mereka selenggarakan. Hal ini dapat kita lihat dalam proses berteater, teater pada dasarnya bukanlah kegiatan individu, teater adalah kerja team. Karena seorang yang akan mempergelarkan teater tidak dapat melakukannya hanya seorang diri, bahkan seorang yang akan pentas dengan monologpun sangat memerlukan kerjasama dengan yang lain, baik untuk penata lampu, pemusik, perias atau yang lainnya. Pebiasaan bekerjasama dan kebutuhan akan kehadiran orang lain inilah yang menjadi modal dasar seorang yang terlibat dalam kegiatan berteater untuk membuka diri terhadap orang lain.

Keempat, menguatnya hubungan pertemanan diantara mereka, beberapa orang mengakui bahwa semenjak menjadi anggota teater pertemanan mereka semakin akrab, bahkan sering sekali muncul kata "keluarga", "ini adalah keluarga kami”. Kata keluarga menunjukkan suatu kedekatan hubungan yang membedakannya dengan kata "pertemanan" dalam artian umum. Hal ini bukan berarti tidak adanya gejolak di dalam "keluarga" tersebut, namun penyelesaian persoalan yangmereka hadapi dilakukan dengan cara-cara dalam suatu anggota keluarga, maka pada konteks ini peran pelatih menjadi penting, karena pelatih tidak hanya bertugas memberi materi berteater, namun juga ikut menyelesaikan persoalan yang mereka hadapi. Di samping itu jika terdapat persoalan antar anggota "keluarga" tidak berlangsung lama, keakraban, canda- tawa, gurauan akan terbangun kembali dalam waktu yang singkat.

Hal ini menunjukkan adanya cara pandang positive terhadap perbedaan keyakinan yang terbangun di kalangan teater pelajar. Karena menurut mereka di teater itu kami dipaksa nutuk menjadi orang lain dari naskah yang kami baca, atau menunggu giliran untuk berdialog, sehingga kami dapat merasakan konflik yang dihadapi oleh orang lain.

Keempat potensi tersebut dapat dikembangkan untuk keperluan membangun kebersamaan di masyarakat melalui proses yang umum dilakukan untuk membangun integrasi. Karena unsur-unsur pembangunnya telah dimiliki oleh siswa yang menjadi anggota pada kelomok teater pelajar di Solo. 


\section{Proses Interaksi}

Proses interaksi adalah proses paling awal untuk membangun suatu kerjasama yang ditandai dengan adanya kecenderungan serta niat positif yang berpotensi menjadi aktivitas bersama. Terkait dengan potensi di atas, hal ini terwujud pada potensi integrasi yang pertama

\section{Proses Identifikasi}

Berangkat dari proses interaksi tersebut, dapat berlanjut ke proses identifikasi. Proses identifikasi ini berlangsung ketika tiap-tiap pihak dapat menerima secara terbuka terhadap keberadaan pihak lain secara utuh. Sehingga, pada hakikatnya, proses identifikasi merupakan proses untuk memahami berbagai karakter, latar belakang, dan kepentingan pihak lain. Hal inilah yang tercermin pada potensi integrasi yang ke dua.

\section{Kerjasama (Cooperation)}

Charles H. Cooley mengungkapkan jika suatu kerjasama dapat mungkin terjadi jika masing-masing pihak sadar bahwa mereka punya kepentingan yang sama. Di saat yang bersamaan pula, mereka memiliki pengetahuan dan pengendalian diri yang cukup untuk mencapai kepentingan tersebut dengan kerjasama. Ketika hal ini sudah dipahami oleh masing-masing pihak, maka proses integrasi akan berjalan lebih mudah karena setiap pihak sudah bersedia untuk membuka diri untuk menjalin kerjasama yang positif.

\section{Proses Akomodasi}

Akomodasi dapat dipahami sebagai langkah untuk menyelesaikan pertentangan tanpa menghancurkan pihak lawan. Dalam proses ini, semaksimal mungkin tiap-tiap pihak mencapai kata sepakat dalam memenuhi tujuan dengan tidak merugikan pihak lain. Pengakuan sesame anggota teater sebagai keluarga merupakan perwujudan dari proses akomodasi, karena dengan keluarga tidak ada keinginan untuk saling menghancurkan, yang terjadi malah sebaliknya yakni mengakomodasi berbagai perbedaan dan pertentangan yang terjadi.

\section{Proses Asimilasi}

Proses asimilasi dalam hal ini dapat dipahamai sebagai suatu cara yang ditandai dengan kegiatan nyata untuk mengurangi perbedaan pada individu atau kelompok yang sedang berkonflik. Proses ini juga meliputi usaha untuk menyatukan persepsi kedua belah pihak dengan cara memperhatikan kepentingan dan tujuan bersama.

\section{Proses Integrasi}

Proses integrasi dapat dipahami sebuah proses penyesuaian antarunsur dalam masyarakat yang majemuk hingga terbentuk keserasian dalam kehidupan sosial bermasyarakat.

Secara berurutan proses tersebut dapat digambarkan sebagai berikut.

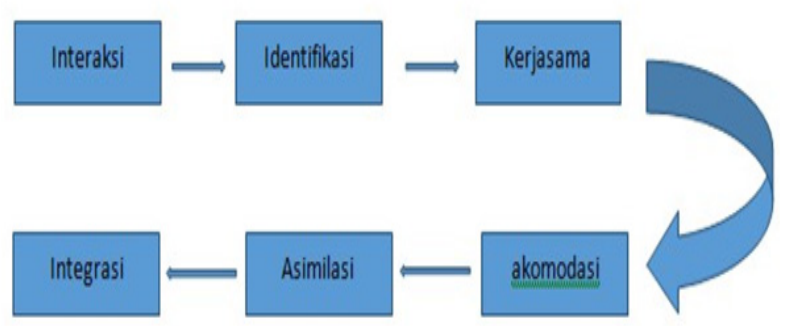

Gambar di atas menjelaskan bahwa proses integrasi berawal dari berlangsungnya interaksi, apabila interaksi berjalan baik dan dalam ruang positif, maka dapat dilakukan langkah berikutnya yakni identifikasi. Pada proses yang kedua ini diperlukan bangunan pemahaman yang kuat, karena dengan pemahaman yang kuat akan mempermudah orang tersebut melakukan identifikasi terhadap yang lain. Dalam proses berteater proses ini dapat dibangun dengan melatih siswa untuk memahami naskah yang diawali dengan melakukan dramatic reading. 
Setelah proses identifikasi berlangsung, langkah selanjutnya adalah mereka akan dapat bekerja sama dengan baik dengan terus melibatkan mereka dalam proses berteater. Dari proses tersebut maka akan terbangun rasa kekeluargaan antar mereka dengan lebih mengutamakan kebersamaan dari pada kepentingan personal. Hal ini adalah suatu proses asimilasi yakni pembauran dan pengenalan lebih dengkat dengan kelompok yang. Dari proses-proses tersebut, maka akan terbangun integrasi social di masyarakat.

Dari proses tersbut, maka kita dapat melihat bahwa teater dapat membangun potensi-potensi integrasi dalam kehidupan social.

\section{Simpulan}

Akhirnya dari uraian di atas, dapat ditarik kesimpulan dari hasil penelitian ini dengan berangkat dari rumusan masalah yang diajukan.

Pertama, kelompok-kelompok teater remaja di Kota Solo selama ini dihadapkan pada berbagai macam bentuk konflik baik secara internal ataupun eksternal. Secara internal potensi-potensi konflik ini pertama muncul diantara anggota kelompok teater yang pada umumnya disebabkan oleh pembagian peran dalam suatu pertunjukan, dan persaingan antar anggota. Kedua potensi tersebut pada dasarnya dapat dimanfaatkan untuk memajukan kelompok teater, namun karena kuatnya ikatan kekeluargaan antar mereka, konflik ini hanya berkembang kedalam yakni seputar hubungan antar anggota. Konflik ini juga dapat muncul dalam bentuk structural yakni antara siswa dengan pihak sekolah, Pembina, pelatih, pimpinan sekolah. Akar masalah nya adalah adanya ketikdakterbukaan dan ketidakberpihakan pihak sekolah terhadap aktifitas positif yang mereka lakukan.

Adapun potensi integrasi yang muncul adalah terbangunnya kebersamaan, kecerdasan, keberterimaan dan pembauran dalam berbagai kegiatan. Namun dari potensi-potensi tersebut yang menarik adalah bahwa kalangan pelajar ini selalu siap menghadapi persoalan. Kemandirian mereka dalam menyelesaikan masalah ini menunjukkan kesipan mental mereka dalam kehidupan social. Selain itu mereka juga mempunyai berbagai alternative dalam menyelesaikan persoalan tersebut. Inilah modal dasar penting yang telah dimiliki oleh anggota kelompok teater yang ada di sekolah-sekolah.

\section{Kepustakaan}

Birgit Bräuchler, 2003, Cyberidentities at War: Religion, Identity, and the Internet in the Moluccan Conflict. Indonesia, Southeast Asia Program Publications at Cornell University (75):123-151.

Coser, Lewis, 1956, The Function Of Social Conflict, New York : Free Press 1956.

Stephen W. Littlejohn, Kathy Domenici, 2007Communication, Conflict, and the Management of Difference, Waveland Press

E.K.D. Sitorus, 2002, The Art of Acting: Seni Peran Untuk Teater, Film dan TV, Jakarta: P.T. Gramedia Pustaka Utama. Eduardo Salvador. 2014, Legislative Theatre: Art for Community Conflict Resolution, From Desires to Laws. Journal Of Conflictology, Volume 5, Issue 12014.

Fontana \& Frey, 2011, Interviewing: The Art of Science, In The Handbook of Qualitatif Researc, $3^{\text {rd }}$ Edition, Thaousend Oaks, Sage Publication.

Iyabobola Olubukunola Ajibola. 2014, Integrating Theatre Approaches in Conflict Management Techniques in Nigeria. Journal of Business Management \& Social Sciences Research (JBM\&SSR) ISSN No: 2319-5614 Volume 3, No.1, January 2014.

Liliweri. Alo, 2005, Prasangka dan Konflik: Komunikasi Lintas Budaya Masyarakat Multikultural, Yogyakarta: LKiS. 
Myra Warren Isenhart and Michael Spangle, 2000 Collaborative Approaches to Resolving Conflict, Thousand Oaks, California: Sage Publication, p.26-7.

Retnowati, 2014, Agama, Konflik, dan Integrasi Sosial (Integrasi Sosial Pasca Konflik Situbondo), Jurnal “Analisa” Volume 21 Nomor 02 Desember 2014, hal. $189-200$.

Robert N. Lussier and Christopher F. Achua, 2010, Leadership: Theory, Application \& Skill Development, Mason: Ohio: South-Western Cengage Learning, p. 212

Subakti, Ramlan, 1992, Memahami Ilmu Politik, Jakarta: Gramedia Widyasarana.

Yudi Aryani, 1999, Panggung Teater Dunia: Perkembangan dan Perubahan Konvensi, Yogyakarta: Pustaka Gondosuli 